\title{
Jurnal
}

\section{Pengaruh Kompensasi Dan Komunikasi Terhadap Semangat Kerja Pegawai Pada \\ Dinas Tenaga Kerja Dan Transmigrasi (Disnakertrans) Kabupaten Bima}

\author{
Busran Muhammad Kasim ${ }^{1 *}$, Rusli ${ }^{2}$ \\ Program Studi Manajemen, STIE Bima, Nusa Tenggara Barat,Indonesia \\ busranmuhammad8@gmail.com ${ }^{1 *}$; radifrusli01.stiebima@gmail.com²
}

Received 17 Oktober 2021| Revised 25 November 2021 | Accepted 30 November 2021

*Korespondensi Penulis

\begin{abstract}
Abstrak
Tujuan dari penelitian ini adalah untuk mengetahui pengaruh kompensasi dan komunikasi terhadap semangat kerja pegawai Dinas Tenaga Kerja Dan Transmigrasi Kabupaten Bima (Disnakertrans) Kabupaten Bima. Jenis penelitian adalah asosiatif dengan metode kuantitatif. Populasi pada penelitian ini pegawai Dinas Tenaga Kerja dan Transmigrasi (Disnakertrans) Kabupaten Bima yang berjumlah 69 orang. Sampel pada penelitian ini yaitu Pegawai Negeri Sipil yang berjumlah 53 orang. Teknik sampling dengan metode purposive sampling. Instrumen penelitian yaitu kuisioner dengan skala liker yang telah diuji validitas dan reliabilitas. Teknik analisis data yang digunakan yaitu uji asumsi klasik, regresi linear berganda, koefisien korelasi, koefisien deteminasi, uji t dan uji F. Berdasarkan hasil uji statistik menunjukkan bahwa Kompensasi berpengaruh positif dan signifikan terhadap semangat kerja pegawai dan Komunikasi berpengaruh positif dan signifikan terhadap semangat kerja pegawai. Secara simultan kompensasi dan komunikasi berpengaruh positif dan signifikan terhadap semangat kerja pegawai pada Dinas Tenaga Kerja dan Transmigrasi (Disnakertrans) Kabupaten Bima. Hal ini dibuktikan dengan nilai F-hitung yang lebih besar dari F-tabel dengan tingkat signifikan yang lebih kecil nilai nilai Alpha $(0.000<0.05)$.
\end{abstract}

Kata Kunci: Kompensasi; Komunikasi; Semangat Kerja

\begin{abstract}
The purpose of this study was to determine the effect of compensation and communication on employee morale of the Department of Manpower and Transmigration, Kabupaten Bima (Disnakertrans), Kabupaten Bima. This type of research is associative with quantitative methods. The population in this study were employees of the Department of Manpower and Transmigration (Disnakertrans) Bima Regency, amounting to 69 people. The sample in this study were 53 Civil Servants. The sampling technique was purposive sampling method. The research instrument is a questionnaire with a liker scale that has been tested for validity and reliability. The data analysis technique used is the classical assumption test, multiple linear regression, correlation coefficient, determination coefficient, t test and $F$ test. Based on the results of statistical tests it shows that compensation has a positive and significant effect on employee morale and communication has a positive and significant effect on morale. employees. Simultaneously compensation and communication have a positive and significant effect on employee morale at the Department of Manpower and Transmigration (Disnakertrans) Bima Regency. This is evidenced by the F-count value that is greater than the F-table with a significantly smaller Alpha value $(0.000<0.05)$.
\end{abstract}

Keywords: Compensation; Communication; Morale 


\section{PENDAHULUAN}

Dinas Tenaga Kerja dan Transmigrasi (Disnakertrans) Kabupaten Bima merupakan Dinas Teknis Daerah yang berada dan bertanggung jawab kepada Bupati melalui Sekretaris Daerah Kabupaten Bima yang mempunyai tugas pokok menyelenggarakan urusan pemerintah daerah di bidang sosial, tenaga kerja dan transmigrasi berdasarkan asas otonomi yang menjadi kewenangan, tugas dekonsentrasi dan pembantuan serta tugas lain sesuai perundang-undangan yang berlaku yang keberadaan kelembagaannya dikukuhkan dengan Peraturan Daerah Kabupaten Bima Nomor 4 Tahun 2016 tentang Pembentukan dan susunan Perangkat Daerah Kabupaten Bima. Pegawai Negeri Sipil (PNS) merupakan perangkat kerja yang sangat menentukan keberhasilannya dalam mencapai tugas pokok dan fungsi, yang banyak sekali berhubungan dengan pelayanan kepada masyarakat baik manusia sebagai individu maupun manusia sebagai kelompok Pegawai Negeri Sipil berkedudukan sebagai unsur aparatur yang bertugas melayani masyarakat secara profesional, jujur, adil, dan merata dalam penyelenggaraan tugas negara pemerintah dan pembangunan.

Semangat kerja memiliki peran penting dalam menentukan kecepatan dan kualitas hasil pekerjaan pegawai semangat kerja adalah melakukan pekerjaan secara lebih giat sehingga dengan demikian pekerjaan akan dapat diharapkan lebih cepat dan lebih baik. . Menurut Tohardi (2012:425) menyatakan "bahwa ada lima alasan pentingnya semangat kerja bagi organisasi atau perusahan adalah dengan adanya semangat kerja yang tinggi dari pegawai maka pekerjaan yang diberikan kepadanya akan dapat diselesaikan dengan waktu yang lebih cepat atau singkat, dengan semangat kerja yang tinggi tentunya dapat mengurangi angka absensi (bolos), dengan semangat kerja yang tinggi pihak organisasi atau perusahaan memperoleh keuntungan dari kecilnya angka kerusakan, dengan semangat kerja yang tinggi otomatis membuat pekerja atau pegawai merasa betah bekerja dengan demikian kecil kemungkinan pegawai pindah bekerja, dengan semangat kerja yang tinggi dapat mengurangi angka kecelakaan". Semangat kerja merupakan hal yang sangat penting dalam setiap usaha kerja sama sekelompok orang dalam suatu organisasi, semangat kerja yang tinggi akan menghasilkan produktivitas kerja yang tinggi dan mempermudah instansi/perusahaan dalam pencapain tujuan yang telah ditetapkan.

Adapun faktor- faktor yang mempengaruhi semangat kerja menurut Nitisemito (2013:112), adalah kepemimpinan, motivasi, komunikasi, hubungan manusiawi, kompensasi dan lingkungan kerja. Menurut penelitian dari Noviyanti (2016) dari 6 faktor yang mempengaruhi semangat kerja, kompensasi dan komunikasi merupakan faktor yang memiliki pengaruh paling besar terhadap semangat kerja. Kompensasi adalah segala sesuatu yang diberikan perusahaan kepada pegawai untuk memenuhi kebutuhan mereka baik dalam bentuk finansial maupun non finansial sebagai balas jasa organisasi/instansi sehingga dapat beroperasi dengan baik dan berusaha untuk mencapai tujuan organisasi. Jika kompensasi yang diterima oleh pegawai layak dan adil, maka semangat kerja pegawai akan meningkat dengan baik (Hasibuan, 2014)

Faktor lain yang mempengaruhi semangat kerja adalah komunikasi. Komunikasi adalah tindakan penyampaian informasi. Komunikasi efektif adalah bagian penting yang dilakukan oleh seorang manajer. Setiap fungsi manajemen seperti perencanaan, pengorganisasian, staf, kepemimpinan, dan pengendalian, membutuhkan keterampilan komunikasi yang efektif. Komunikasi dalam organisasi dapat terjadi dalam berbagai bentuk; mulai dari tatap muka yang melibatkan ekspresi wajah dan gerakan tubuh; untuk komunikasi tertulis dalam bentuk memo, surat dan laporan; melalui jaringan dimana orang dengan orang dan orang dengan peralatan berinteraksi secara langsung..Komunikasi yang terjadi dalam suatu organisasi, dapat bersifat formal dan dapat juga bersifat informal. Komunikasi organisasi ini seringkali melibatkan komunikasi kelompok, antar pribadi dan juga komunikasi publik. Komunikasi dalam organisasi menjadi sistem aliran yang menghubungkan dan membangkitkan kinerja antar bagian dalam organisasi sehingga menghasilkan sinergi. Sehingga komunikasi dalam organisasi selain ikut andil membangun iklim organisasi juga ikut membangun budaya organisas serta semangat kerja pegawai. Komunikasi menurut (Keith Davis, 2010) komunikasi merupakan proses penyampaian dan pemahaman dari seseorang kepada orang lain

Berdasarkan hasil penelitian pada Dinas Tenaga Kerja Dan Transmigrasi Kabupaten Bima dalam meningkatkan semangat kerja pegawainya dihadapkan pada fenomena yang timbul bahwa terdapat jarak dalam komunikasi antara pimpinan dengan pegawai komunikasi vertical yakni atasan dengan bawahan dan komunikasi horizontal yakni antara pegawai dengan pegawai kurang terjalin dengan baik. Informasi dari bawahan (pegawai) sering tidak sampai kepada atasan (pimpinan) begitu sebaliknya pimpinan juga kurang memberikan informasi dan perintah kepada pegawai sehingga dalam pekerjaan sering tidak 
terjadi miss communication. Tentunya hal ini juga mempengaruhi kinerja dan semangat kerja pegawai yang bersangkutan, yang berdampak pada penyelesaian tugas pekerjaan tidak maksimal.

Faktor lain yang harus diperhatikan yaitu pembagian kompensasi dan insentif. Menurut (Mangkunegara, 2015) kompensasi merupakan sesuatu yang dipertimbangkan sebagai suatu yang sebanding. Permasalahan yang ada yaitu dimana kompensasi yang diberikan kurang proporsional. Hal ini sering terlihat adanya pegawai dengan beban tugas yang banyak sehingga berdampak melebihi jam kerja, namun demikian kompensasi yang diberikan tidak seimbang dengan tanggung jawabnya yang berdampak pada menurunnya semangat kerja pegawai. Pemberian kompensasi yang baik kepada para pegawai yang berprestasi akan berdampak pada semangat kerja yang tinggi dari para pegawai itu sendiri sehingga pegawai akan lebih bersemangat dalam bekerja. Hal ini sejalan dengan pendapat Nitisemito (2013) bahwa kompensasi adalah sistem yang paling efektif sebagai pendorong yang mampu mengikat dan sekaligus menimbulkan semangat kerja pegawai

Berdasarkan penjelasan tersebut, terlihat bahwa Dinas Tenaga Kerja Dan Transmigrasi Kabupaten Bima berusaha memberikan kompensasi dan melakukan komunikasi yang baik untuk meningkatkan semangat kerja pegawainya. Bagi Dinas Tenaga Kerja Dan Transmigrasi Kabupaten Bima semangat kerja pegawai sangat diperlukan untuk meningkatkan tujuan organisasi sehingga tujuan dari penelitian ini adalah untuk mengetahui pengaruh kompensasi dan komunikasi terhadap semangat kerja pegawai Dinas Tenaga Kerja Dan Transmigrasi Kabupaten Bima (Disnakertrans) Kabupaten Bima.

\section{Kompensasi}

Kompensasi adalah semua jenis penghargaan yang berupa uang atau bukan uang yang diberikan kepada pegawai secara layak dan adil atas jasa mereka dalam mencapai tujuan organisasi", Menurut (Simamora, 2014) mendefinisikan : "Kompensasi meliputi imbalan finansial dan jasa nirwujud serta tunjangan yang diterima oleh para pegawai sebagai bagian dari hubungan kepegawaian. Kompensasi merupakan apa yang diterima oleh para pegawai sebagai ganti frkontribusi mereka kepada organisasi”. Disimpulkan bahwa kompensasi merupakan interaksi antara pegawai dengan organisasi, yang berupa timbal balik dari jasa atau tenaga yang dikeluarkan oleh pegawai dan penghargaan dari organisasi dalam bentuk upah atau fasilitas lainnya. Menurut (Panggabean, 2013) mengemukakan Kompensasi dapat didefinisikan sebagai setiap bentuk penghargaan yang diberikan kepada pegawai sebagai balas jasa atas kontribusi yang mereka berikan kepada organisasi. Sistem kompensasi yang diterapkan organisasi/perusahaan merupakan salah satu cara untuk meningkatkan moral/semangat kerja pegawai. Menurut Rivai (2014) kompensasi dapat dibedakan menjadi :

1. Kompensasi Finansial terdiri dari kompensasi tidak langsung dan kompensasi langsung. Kompensasi langsung terdiri dari pembayaran pegawai dalam bentuk upah, gaji, bonus atau komisi. Kompensasi tidak langsung atau benefit, terdiri dari semua pembayaran yang tidak tercakup dalam kompensasi finansial langsung yang meliputi hiburan, berbagai macam asuransi jasa seperti perawatan anak atau kepedulian keagamaan dan sebagainya.

2. Kompensasi Non Finansial yaitu penghargaan non finansial seperti pujian, menghargai diri sendiri dan pengakuan yang dapat mempengaruhi motivasi kerja pegawai, produktivitas dan kepuasan.

Kompensasi (compensation) meliputi imbalan finansial dan jasa nirwujud serta tunjangan yang diterima oleh para pegawai sebagai bagian dari hubungan kepegawaian. Kompensasi merupakan apa yang diterima oleh para pegawai sebagai ganti kontribusi mereka kepada organisasi”. Menurut Simamora (2014) indikator yang disajikan dalam menilai kompensasi adalah:

1. Gaji adalah kompensasi yang diberikan kepada seorang pegawai secara periodik (sebulan sekali). Pegawai yang menerima gaji, pada umumnya telah menjadi pegawai tetap dan telah lulus dari masa percobaan.

2. Tunjangan adalah kompensasi yang diberikan perusahaan kepada para pegawainya, karena pegawai tersebut dianggap telah ikut berpartisipasi dengan baik dalam mencapai tujuan perusahaan. Contohmya : tunjangan jabatan, keluarga, transport, perumahan, dan sebagainy

3. Insentif atau Bonus. Kompensasi yang diberikan kepada pegawai tertentu karena keberhasilan prestasi atas prestasinya. Contohnya insentif 5\% dari gaji bagi pegawai yang melakukan penjualan melampaui target yang telah ditentukan.

4. Penghargaan atas Prestasi Kerja. Penghargaan diberikan kepada pegawai atas prestasi yang telah dilakukan pegawai selama bekerja. Penghargaan tersebut bisa berupa dalam fasilitas. 


\section{Komunikasi}

Komunikasi adalah proses penyampaian pikiran atau perasaan oleh seseorang kepada orang lain dengan menggunakan lambang-lambang yang bermakna bagi kedua pihak, dalam situasi yang tertentu komunikasi menggunakan media tertentu untuk merubah sikap atau tingkah laku seorang atau sejumlah orang sehingga ada efek tertentu yang diharapkan, (Effendy, 2013).

Menurut Wilson (2012:360), "komunikasi adalah suatu proses penyampain informasi dari. pengirim (sender) ke penerima pesan (receiver) dengan menggunakan berbagai media yang efektif sehingga pesan tersebut dapat dengan jelas dan mudah dipahami oleh penerima pesan tersebut.. Dalam kegiatan tersebut, pengirim pesan berupaya menggunakan bahasa dan memilih media yang tepat, demikian sebaliknya penerima pesan berupaya agar pesan yang diterima dapat dipahami dengan jelas sehingga ada umpan balik dari pesan tersebut. Dari pengertian diatas dapat disimpulkan bahwa proses komunikasi merupakan suatu proses berinteraksi atau terjadinya transaksi dengan maksud dimana komponen-komponennya saling terkait dan para komunikator beraksi dan bereaksi.

Setiap proses komunikasi memiliki tujuan untuk efisiensi dan efektivitas. Efisiensi maksudnya adalah dengan sumber daya yang ada, tetap diusahakan sebuah proses komunikasi mencapai hasil yang maksimal. Ketika seorang komunikator menyampaikan pesan, materi pesan yang disampaikan sebisa mungkin mendapatkan feed back yang positif dari penerima pesannya, efektivitas diartikan sebagai cara mengoptimalkan setiap fungsi komponen dalam proses komunikasi. Setiap unsur yang terlibat dalam proses komunikasi, baik itu komunikator, media, pesan, maupun komunikan harus memainkan perannya secara tepat untuk menciptakan iklim yang kondusif sehingga proses komunikasi mencapai tujuannya Komala (2009:139). Menurut Hutapea dan Nurianna (2008:28) indikator kemampuan komunikasi meliputi:

1. Pengetahuan (knowledge) yang meliputi:

a. Mengetahui dan memahami pengetahuan di bidangnya masing masing yang menyangkut tugas dan tanggung jawabnya dalam bekerja.

b. Mengetahui pengetahuan yang berhubungan dengan peraturan, prosedur, teknik yang baru.

c. Mengetahui bagaimana menggunakan informasi, peralatan dan taktik yang tepat dan benar.

2. Keterampilan (skills) yang meliputi:

a. Kemampuan dalam berkomunikasi dengan baik secara tulisan.

b. Kemampuan dalam berkomunikasi dengan jelas secara lisan.

3. Sikap (Attitude) yang meliputi:

a. Memiliki kemampuan dalam berkreativitas dalam bekerja.

b. Adanya semangat kerja yang tinggi.

c. Memiliki kemampuan dalam perencanaan/pengorganisasian.

\section{Semangat Kerja}

Menurut Nitisemito (2013:77), menjelaskan bahwa: Semangat kerja dapat diartikan juga sebagai suatu iklim atau suasana kerja yang terdapat di dalam suatu organisasi yang menunjukkan rasa kegairahan di dalam melaksanakan pekerjaan dan mendorong mereka untuk bekerja secara lebih baik dan lebih produktif. Menurut Widodo (2015:104) menjelaskan bahwa: semangat kerja adalah mencerminkan kondisi pegawai dalam lingkungan kerjanya, bila semangat kerja baik maka perusahaan memperoleh keuntungan, seperti rendahnya tingkat absensi, kecilnya keluar masuk pegawai dan meningkatkan produktivitas tenaga kerja.

Dari definisi diatas dapat disimpulkan bahwa semangat kerja merupakan cermin dari kondisi pegawai dalam lingkungan kerjanya dan ekspresi serta mental individu atau kelompok yang menunjukan rasa senang dan bahagia dalam melakukan pekerjaannya, sehingga merasa bergairah dan mampu bekerja secara lebih cepat dan lebih baik demi tercapainya suatu tujuan organisasi. Menurut Nitisemito dalam Darmawan (2013:80) faktor-faktor untuk mengukur semangat kerja adalah :

1. Absensi. Karena absensi menunjukkan ketidakhadiran pegawai dalam tugasnya. Hal ini termasuk waktu yang hilang karena sakit, kecelakaan dan pergi meninggalkan pekerjaan karena alasan pribadi tanpa diberi wewenang. yang tidak diperhitungkan sebagai absensi adalah diberhentikan untuk sementara, tidak ada pekerjaan, cuti yang sahlibur dan pemberhentian kerja.

2. Kerja sama. Kerja sama dalam bentuk tindakan kolektif seseorang terhadap orang lain. Kerjasama dapat dilihat dari kesediaan pegawai untuk bekerja sama dengan rekan kerja atau dengan atasan mereka berdasarkan untuk mencapai tujuan bersama. Selain itu, kerjasama dapat dilihat dari 
kesediaan untuk saling membantu di antara rekan sekerja sehubungan dengan tugas-tugasnya dan terlihat keaktifan dalam kegiatan organisasi.

3. Kepuasan kerja. Kepuasan kerja sebagai keadaan emosional yang menyenangkan atau tidak menyenangkan di mana para pegawai memandang pekerjaan mereka.

4. Kedisiplinan. Kedisiplinan sebagai suatu sikap dan tingkah laku yang sesuai peraturan organasasi dalam bentuk tertulis maupun tidak. Dalam prakteknya bila suatu organisasi telah mengupayakan sebagian besar dari peraturan-peraturan yang ditaati oleh sebagian besar pegawai, maka kedisiplinan telah dapat ditegakkan. Dan harus dapat di terapkan di perusahaan.

Untuk mengetahui apakah seseorang memiliki semangat kerja yang tinggi atau rendah maka dapat dilihat dari ciri-ciri yang terlibat dalam sikap sehari-hari. indikator semangat kerja yang dikemukakan oleh Nitisemito dalam Danang Ersanto Nugroho (2015:4), semangat kerja pegawai berkaitan dengan:

1. Produktivitas pegawai. Menurutnnya produktivitas dapat terjadi karena kemalasan, menunda pekarjaan, dan sebagainya. Bila terjadi penurunan produktivitas, maka hal ini berarti indikasi dalam organisasi tersebut telah terjadi penurunan semangat kerja

2. Tingkat Absensi. Pada umumnya, bila semangat kerja menurun, maka pegawai dihinggapi rasa malas untuk bekerja. Apalagi kompensasi atau upah yang diterimanya tidak dikenakan potongan saat mereka tidak masuk bekerja. Dengan demikian dapat menimbulkan penggunaan waktu luang untuk mendapatkan penghasilan yang lebih tinggi, meski hanya untuk sementara.

3. Tingkat perpindahan pegawai (Labour Turnover)

Keluar masuk pegawai yang meningkat terutama disebabkan pegawai mengalami ketidaksenangan saat mereka bekerja, sehingga mereka berniat bahkan memutuskan untuk mencari tempat pekerjaan lain yang lebih sesuai dengan alasan mencari kenyamanan dalam bekerja. Manajer harus waspada terhadap gejala-gejala seperti ini.

4. Kegelisahan pegawai. Kegelisahan tersebut dapat berbentuk ketidaktenangan dalam bekerja, keluh kesah serta hal-hal lain. Terusiknya kenyamanan pegawai memungkinkan akan berlanjut pada perilaku yang dapat merugikan organisasi itu sendiri.

5. Tuntutan dari pegawai. Tuntutan merupakan perwujudan dari ketidakpuasan, dimana pada tahap tertentu akan menimbulkan keberanian untuk mengajukan tuntunan. Organisasi harus mewaspadai tuntutan secara masal dari pihak pegawai.

\section{Pengaruh Kompensasi Terhadap Semangat Kerja}

Kompensasi memiliki arti penting karena kompensasi mencerminkan upaya organisasi dalam mempertahankan dan meningkatkan kesejahteraan pegawainya. Pengalaman menunjukkan bahwa kompensasi yang tidak memadai dapat menurunkan prestasi kerja, motivasi kerja, dan kepuasan kerja pegawai, bahkan dapat menyebabkan pegawai yang potensial keluar pekerjaanya. Kompensasi sebagai alat manajemen untuk meningkatkan motivasi kerja, meningkatkan produktivitas, dan mempengaruhi semangat kerja.

Pemberian kompensasi yang diterapkan secara benar kepada pegawai akan mengurangi rasa kekhawatiran pegawai terhadap masalah ekonomi dan kebutuhan sehari-hari pegawai, karena pegawai dapat memenuhinya dengan kompensasi yang diterima dari kantor tempat dia bekerja. Keadaan tersebut akan merangsang pegawai untuk memberikan imbalan dalam wujud patuh pada peraturan kerja dan tanggung jawab terhadap kelancaran kantor. Jika kompensasi yang diterima oleh pegawai layak dan adil, maka semangat kerja pegawai akan meningkat dengan baik. Hal ini diperkuat dengan hasil penelitian Danti (2014) menunjukkan bahwa kompensasi langsung dan tidak langsung berpengaruh terhadap semangat kerja pegawai. Dari kedua variabel tersebut, variabel kompensasi tidak langsung mempunyai pengaruh yang dominan terhadap semangat kerja pegawai. Dengan demikian penelitian ini juga mengajukan hipotesis kompensasi mempunyai pengaruh positif terhadap semangat kerja.

\section{Pengaruh Komunikasi Terhadap Semangat Kerja}

Faktor lain yang mempengaruhi semangat semangat kerja pegawai adalah komunikasi yang terjalin antara atasan dengan bawahan serta kompensasi yang diterima pegawai. Hal ini diperkuat dengan hasil penelitian Dwi Agung Nugroho Arianto (2015) yang menunjukkan bahwa ada pengaruh positif dan signifikan komunikasi organisasi terhadap semangat kerja. Dengan demikian komunikasi yang baik pada suatu lembaga pemerintahan memiliki pengaruh terhadap semangat kerja pegawai. Hal ini berarti dengan komunikasi yang intens permasalahan dalam organisasi akan mudah terselesaikan. Komunikasi berpengaruh positif terhadap semangat kerja pegawai. 


\section{Pengaruh Kompensasi dan Komunikasi Terhadap Semangat Kerja}

Pemberian kompensasi yang baik kepada para pegawai yang berprestasi akan berdampak pada semangat kerja yang tinggi dari para pegawai itu sendiri. Pemberian kompensasi serta terjalinnya komunikasi yang baik dalam suatu organisasi dapat lebih memberikan rangsangan kepada pegawai sehingga pegawai memperoleh penghasilan lain diluar gaji pokok yang diterima setiap bulannya dan dapat lebih meningkatkan semangat kerja pegawai sehingga tujuan perusahaan dapat tercapai dengan baik. Semangat kerja pegawai sangat penting artinya dalam menunjang kelancaran pekerjaan yang menjadi beban dan tanggung jawab dari suatu organisasi. Oleh karena itu merupakan suatu kewajiban yang harus dilaksanakan untuk meningkatkan semangat kerja pegawai dan hasil kerja yang diperoleh sesuai dengan yang diinginkan. Seperti yang dikemukakan oleh Alex S. Nitisemito (2011) menyatakan sebagai berikut: "Jelas bahwa kompensasi adalah sistem yang paling efektif sebagai pendorong yang mampu mengikat dan sekaligus menimbulkan semangat kerja."

Semangat kerja merupakan hal yang sangat penting dalam setiap uasaha kerja sama sekelompok orang dalam suatu organisasi, semangat kerja yang tinggi akan menghasilkan produktivitas kerja yang tinggi dan mempermudah instansi/perusahaan dalam pencapain tujuan yang telah ditetapkan. Adapun faktor- faktor yang mempengaruhi semangat kerja menurut Nitisemito (2013:112), adalah kepemimpinan, motivasi, komunikasi, hubungan manusiawi, kompensasi dan lingkungan kerja. Menurut penelitian dari Noviyanti (2016) dari 6 faktor yang mempengaruhi semangat kerja, kompensasi dan komunikasi merupakan faktor yang memiliki pengaruh paling besar terhadap semangat kerja.

\section{Kerangka Pemikiran}

Terdapat suatu keterikatan antara kompensasi dan komunikasi terhadap semangat kerja yang dapat menaikkan dan menurunkan semangat kerja seorang pegawai. Berikut gambaran pengaruh kompensasi dan komunikasi terhadap semangat kerja pegawai.

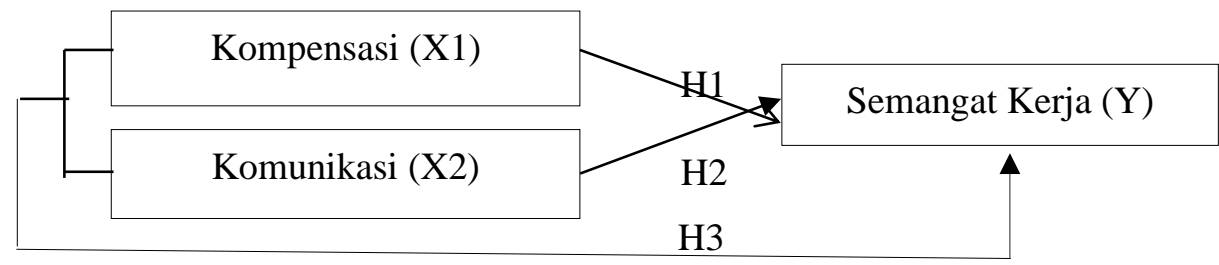

\section{Hipotesis Penelitian}

\section{Gambar 1. Kerangka Pemikiran}

Hipotesis merupakan jawaban sementara terhadap rumusan masalah penelitian, oleh karena itu jawaban yang diberikan baru didasarkan pada teori yang relevan belum didasarkan pada fakta-fakta empiris yang diperoleh melalui pengumpulan data (Sugiono, 2013). Berdasarkan landasan teori dan kerangka pikir dapat diajukan hipotesis sebagai berikut :

H1 : Kompensasi berpengaruh positif dan signifikan secara parsial terhadap semangat kerja pegawai pada Dinas Tenaga Kerja dan Transmigrasi (Disnakertrans) Kabupaten Bima.

$\mathrm{H} 2$ : Komunikasi berpengaruh positif dan signifikan secara parsial terhadap semangat kerja pegawai pada Dinas Tenaga Kerja dan Transmigrasi (Disnakertrans) Kabupaten Bima

H3 : Kompensasi dan komunikasi berpengaruh positif dan signifikan secara simultan terhadap semangat kerja pegawai pada Dinas Tenaga Kerja dan Transmigrasi (Disnakertrans) Kabupaten Bima

\section{METODE}

Desain penelitian yang digunakan adalah penelitian asosiatif kausal. Menurut Sugiyono (2017:36) merupakan penelitian yang bertujuan untuk melihat dan mengetahui hubungan antara dua variabel atau lebih. Desain penelitian berfungsi untuk membantu melaksanakan penelitian agar dapat berjalan dengan baik. Metode analisis data yang digunakan untuk menganalisis masalah yang ada dengan metode analisis deskriptif dan kuantitatif yang dinyatakan dalam bentuk skala numerik atau angka, seperti: data kualitatif yang diangkakan (scoring) Dalam penelitian ini sumber data yang diperoleh dibedakan menjadi dua jenis yaitu data primer dan data sekunder. Dalam penelitian ini data primer berupa kuesioner yang diberikan kepada perangkat desa Sondosia Kecamatan Bolo. Data sekunder umumnya berupa bukti, catatan atau laporan. Populasi pada penelitian ini pegawai Dinas 
Tenaga Kerja dan Transmigrasi (Disnakertrans) Kabupaten Bima yang berjumlah 69 orang yang terdiri dari 53 Pegawai Negeri Sipil (PNS) dan 16 Pegawai Honor. Sampel pada penelitian Pegawai Negeri Sipil (PNS) yang berjumlah 53 orang. Teknik sampling dengan menggunakan teknik purposive sampling yaitu penentuan sampel dengan kriteria dan pertimbangan tertentu. Teknik pengumpulan data yang digunakan adalah melalui observasi, wawancara, dan kuesioner. Kemudian dalam pengumpulan data primer ini peneliti mengkombinasikan ketiganya yang ditujukan kepada para responden. skala pengukuran interval dengan model Skala Likert. Skala ini biasanya menggunakan skala 1-5 yang memiliki nilai ujung yang menyatakan sangat setuju dan sangat tidak setuju.

Metode analisis data menggunakan uji validitas dan uji reliabilitas, uji asumsi klasik, regresi linier berganda, yang bertujuan untuk mengidentifikasi arah dan besaran dari pengaruh atau hubungan antara dua atau lebih variabel independen terhadap variabel dependen (Sekaran, 2013). Selanjutnya, dilakukan pengujian atas hipotesis-hipotesis yang diajukan dalam penelitian ini, yang dibedakan antara pengujian secara parsial (uji $t$ ) dan pengujian secara simultan (uji $F$ ). Uji $t(t$-test) untuk mengidentifikasi bagaimana pengaruh dari variabel-variabel independen secara parsial atau individu terhadap variabel dependen; dengan kriteria jika diperoleh nilai Sig. $t<\alpha(0,05)$ maka dinyatakan variabel independen memiliki pengaruh parsial yang signifikan terhadap variabel dependen. Uji $F$ ( $F$-test) untuk mengidentifikasi bagaimana pengaruh dari variabel-variabel independen secara simultan atau serempak terhadap variabel dependen; dengan kriteria jika diperoleh nilai Sig. $F<\alpha(0,05)$ maka dinyatakan variabel-variabel independen memiliki pengaruh simultan yang signifikan terhadap variabel dependen (Sekaran, 2013). Analisis statistic dapat dilakukan dengan menggunakan Analisis Program SPSS V 23.0 (Ghozali, 2016).

\section{HASIL DAN PEMBAHASAN}

\section{Deskriptif Data}

Penelitian ini terdiri dari tiga variabel yaitu dua variabel indpenden dan satu variabel dependen. Dua variabel dependen adalah kompensasi dan komunikasi, sedangkan satu variabel dependen adalah semangat kerja. Hasil analisis deskriptif adalah sebagai berikut:

Tabel 1. Hasil Perhitungan Data Tiga Variabel

\begin{tabular}{cccc}
\hline \multicolumn{4}{c}{ Descriptive Statistics } \\
\hline $\mathrm{Y}$ & Mean & Std. Deviation & $\mathrm{N}$ \\
\hline $\mathrm{X} 1$ & 40.1132 & 4.03189 & 53 \\
\hline $\mathrm{X} 2$ & 39.0377 & 4.85546 & 53 \\
\hline & 39.0566 & 5.26386 & 53 \\
\hline
\end{tabular}

Sumber : Data Primer, diolah 2021

Hasil analisis deskriptif pada tabel 1 menjelaskan bahwa nilai rata-rata responden memberikan jawaban setuju terhadap variabel X1 sebesar 39,04\%, dan nilai rata-rata jawaban responden variabel X2 adalah 39,06, sedangkan variabel $\mathrm{Y}$ adalah sebesar $40,11 \%$.

\section{Uji Validitas dan Reliabilitas}

Uji validitas disini menggunakan taraf signifikansi pada $a=5 \%$. Suatu item dikatakan valid apabila $r$ hitung lebih besar dari $r$ kritis. Besarnya $r$ tiap butir pertanyaan dapat dilihat dari hasil analisis pada kolom Corrected items atau total correlation (Data terlampir). Hasil pengolahan data menunjukkan bahwa butir-butir yang digunakan untuk mengindentifikasi variabel bebas dan terikat adalah valid. Dengan demikian seluruh indikator dalam penelitian ini dapat digunakan untuk analisis selanjutnya.

Suatu instrumen disebut reliabel jika koefisien $\alpha$ (alpha) lebih besar dari 0,600. Dari hasil pengolahan data dikatehui variabel Kompensasi (X1) memiliki koefisien $\alpha=0,808$; variabel Komunikasi (X2) memiliki koefisien $\alpha=0,888$ dan variabel Kepuasan Kerja (Y) memiliki koefisien $\alpha$ $=0,676$. Dengan demikian diputuskan bahwa butir-butir yang digunakan sebagai instrument variabel penelitian adalah reliabel atau konsisten. Hasil uji reliabilitas dapat disajikan pada tabel berikut : 
Tabel 2. Hasil Uji Reliabilitas

\begin{tabular}{cccc}
\hline Variabel & Cronbach Alpha & Standar Reliabilitas & Keterangan \\
\hline Kompensasi & 0,808 & 0,600 & Reliabel \\
\hline Komunikasi & 0,888 & 0,600 & Reliabel \\
\hline Semangat Kerja & 0,676 & 0,600 & Reliabel \\
\hline
\end{tabular}

Sumber : Data Primer diolah dengan SPSS

\section{Uji Persyaratan Analisis Data}

\section{Uji Normalitas}

Uji normalitas bertujuan untuk menguji apakah suatu data berdistribusi normal atau tidak. Distribusi data dinyatakan normal jika koefisien Asymp Sig. (2-tailed) yang dihasilkan lebih besar dari 0,05. Uji normalitas dengan Uji Kolmogorov-Smirnov adalah sebagai berikut :

Tabel 3. Hasil Uji Kolmogorov-Smirnov One-Sample Kolmogorov-Smirnov Test

\begin{tabular}{llrrr}
\hline & & X1 & X2 & \multicolumn{1}{c}{ Y } \\
\hline \multirow{2}{*}{ Normal Parameters $^{\mathrm{a}}$} & & 53 & 53 & 53 \\
\hline \multirow{2}{*}{ Most Extreme Differences } & Mean & 39.0377 & 39.0566 & 40.1132 \\
\cline { 2 - 5 } & Std. Deviation & 4.85546 & 5.26386 & 4.03189 \\
\cline { 2 - 5 } & Absolute & .201 & .267 & .130 \\
\cline { 2 - 5 } & Positive & .201 & .139 & .112 \\
\cline { 2 - 5 } & Negative & -.112 & -.267 & -.130 \\
\hline Kolmogorov-Smirnov Z & & 1.465 & 1.941 & .948 \\
\hline Asymp. Sig. (2-tailed) & & .274 & .024 & .390 \\
\hline
\end{tabular}

a. Test distribution is Normal.

Sumber : Data Primer diolah dengan SPSS

Tabel 3 output menunjukkan bahwa nilai $P$-value yaitu Asymp Sig. (2-tailed) rata-rata lebih besar dari 0,05, shingga dapat disimpulkan bahwa model uji normalitas dengan Asymp Sig. (2-tailed) telah memenuhi syarat normalitas data.

\section{Uji Multikolinieritas}

Untuk menguji adanya multikolinearitas dapat dilihat melalui nilai tolerance dan nilai Variance Inflantion Factor (VIF) untuk setiap variabel bebas. Apabila nilai tolerance di atas 0,10 dan VIF kurang dari 10 maka dapat dikatakan tidak terdapat gejala multikolinearitas. Hasil Uji multikolinearitas disajikan pada tabel 4 sebagai berikut :

Tabel 4. Hasil Uji Multikolinearitas

\section{Coefficients $^{\mathrm{a}}$}

\begin{tabular}{|c|c|c|c|}
\hline \multirow[b]{2}{*}{ Mode } & & \multicolumn{2}{|c|}{ Collinearity Statistics } \\
\hline & & Tolerance & VIF \\
\hline \multirow[t]{3}{*}{1} & (Constant) & & \\
\hline & $\mathrm{X} 1$ & .866 & 1.154 \\
\hline & $\bar{X} 2$ & .866 & 1.154 \\
\hline
\end{tabular}

a. Dependent Variable: Y

Sumber : Data Primer diolah dengan SPSS

Berdasarkan hasil uji multikolinearitas yang ditunjukkan pada tabel 4 di atas diketahui bahwa nilai tolerance yang besarnya di atas 0,1 dan nilai VIF dibawah 10 menunjukkan bahwa tidak terdapat multikolineritas diantara variabel bebas, sehingga tidak terjadi pelanggaran asumsi multikolinearitas pada model persamaan regresi. 


\section{Uji Heteroskedastisitas}

Untuk mendeteksi adanya heteroskedastisitas pada penelitian ini menggunakan gambar Scatterplot. Hasil Uji heteroskedastisitas ditunjukkan pada grafik di bawah ini.

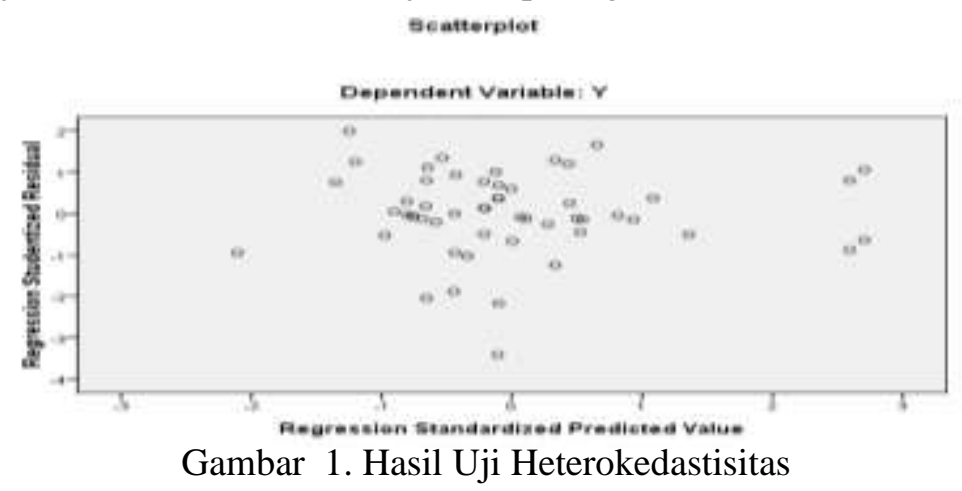

Hasil pengujian heteroskedastisitas pada gambar grafik di atas menunjukkan, titik-titik yang menyebar secara acak, tidak membentuk suatu pola tertentu yang jelas, serta tersebar baik di atas maupun di bawah angka 0 (nol) pada sumbu $\mathrm{Y}$, hal ini berarti tidak terjadi penyimpangan asumsi klasik heteroskedastisitas pada model regresi yang dibuat.

\section{Uji Linieritas Data}

\section{Uji Regresi Liniear Berganda}

Penelitian ini menggunakan analisis regresi untuk memprediksi seberapa jauh perubahan nilai variabel terikat Semangat kerja, bila nilai variabel bebas kompensasi dan komunikasi dirubah-rubah atau dinaik turunkan. Hasil alat analisis regresi berganda yaitu :

Tabel 6. Uji Regresi Linier Berganda

\begin{tabular}{|c|c|c|c|c|c|c|}
\hline \multicolumn{7}{|c|}{ Coefficients $^{\mathrm{a}}$} \\
\hline \multirow{2}{*}{\multicolumn{2}{|c|}{ Model }} & Unstandardize & Coefficients & $\begin{array}{c}\text { Standardized } \\
\text { Coefficients }\end{array}$ & & \\
\hline & & $\mathrm{B}$ & Std. Error & Beta & $\mathrm{T}$ & Sig. \\
\hline \multirow[t]{3}{*}{1} & (Constant) & 7.923 & 6.147 & & 1.289 & .203 \\
\hline & $\mathrm{X} 1$ & .543 & .099 & .654 & 5.495 & .000 \\
\hline & $\overline{\mathrm{X} 2}$ & .282 & .091 & .368 & 3.089 & .003 \\
\hline
\end{tabular}

a. Dependent Variable: Y

Sumber : Data Primer diolah dengan SPSS

Dari hasil perhitungan variabel bebas pada tabel output di atas dapat disusun persamaan regresi

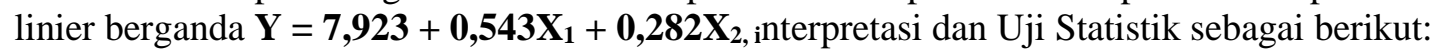

Nilai konstanta persamaan regresi sebesar 7,923 angka tersebut menunjukkan bahwa jika X1 (Kompensasi), $\mathrm{X} 2$ (Komunikasi) konstan atau $\mathrm{X}=0$, maka semangat kerja pegawai bernilai sebesar 7,923. X1 (Kompensasi) menunjukkan nilai koefisien sebesar (0.543). Hal ini berarti bahwa jika terjadi kenaikan faktor kompensasi sebesar $1 \%$ maka semangat kerja pegawai juga akan mengalami kenaikan sebesar variabel pengalinya 0.543 dengan asumsi variabel independen yang lain dianggap konstan. X2 (Komunikasi) menunjukkan nilai koefisien sebesar $(0,282)$. Hal ini berarti bahwa jika terjadi kenaikan faktor komunikasi sebesar sebesar 1\% maka semangat kerja pegawai juga akan mengalami kenaikan sebesar variabel pengalinya 0,282 dengan asumsi variabel independen yang lain diaggap konstan.

\section{Uji Koefesien Korelasi (R)}

Analisa korelasi (R) digunakan untuk mencari arah dan kuatnya hubungan antara dua variabel atau lebih, baik hubungan yang bersifat simetris, kausal dan reciprocal.. Nilai koefisien korelasi dapat ditunjukkan pada tabel sebagai berikut: 
Tabel 7. Koefisien Korelasi

Model Summary ${ }^{b}$

\begin{tabular}{lrrrrr}
\hline Model & R & R Square & Adjusted R Square & $\begin{array}{c}\text { Std. Error of the } \\
\text { Estimate }\end{array}$ & Durbin-Watson \\
\hline 1 & $.622^{\mathrm{a}}$ & .387 & .362 & 3.21977 & 2.199 \\
\hline
\end{tabular}

a. Predictors: (Constant), X2, X1

b. Dependent Variable: Y

Sumber : Data Primer diolah dengan SPSS

Berdasarkan tabel 7 di atas, nilai koefisien korelasi adalah sebesar 0.622. Sehingga dapat dinyatakan terdapat hubungan yang positif antara variabel kompensasi dan komunikasi terhadap semangat kerja pegawai Dinas Tenaga Kerja dan Transmigrasi (Disnakertrans) Kabupaten Bima dapat dikategorikan pada hubungan yang cukup kuat.

\section{Uji Koefisien Determinan $\left(\mathbf{R}^{2}\right)$}

Koefisien determinasi $\left(\mathrm{R}^{2}\right)$ pada intinya mengukur seberapa jauh kemampuan sebuah model menerangkan variasi variabel dependen. Nilai koefisien determinasi adalah antara 0 dan 1 . Nilai R2 yang kecil berarti kemampuan variabel-variabel independen dalam menjelaskan variabel dependen sangat terbatas. Pada tabel 7 di atas juga memperlihatkan nilai koefisien determinasi (adjusted R2) adalah 0.362 , artinya sebesar $36,2 \%$ variabel semangat kerja dapat dijelaskan dari kedua variabel kompensasi dan komunikasi, sedangkan sisanya $(100 \%-36,2 \%=63,8 \%)$ dijelaskan oleh sebab-sebab yang lain diluar model penelitian ini. Adapun beberapa faktor yang dapat mempengaruhi semangat kerja pegawai pada Dinas Tenaga Kerja dan Transmigrasi (Disnakertrans) Kabupaten Bima diantaranya motivasi kerja, kecerdasan, kompensasi, stres kerja, promosi jabatan, pelatiahan dan pendidikan serta lingkungan kerja.

\section{Pengujian Hipotesis} simultan.

Pada penelitian ini terdapat dua hipotesis yang di uji secara parsial dan satu hipotesis diuji secara

\section{Pengujian Hipotesis Parsial}

Hasil uji hipotesis secara parsial dapat diuraikan pada tabel di bawah ini.

Tabel 8. Hasil Uji-t (Parsial) Coefficients $^{\mathrm{a}}$

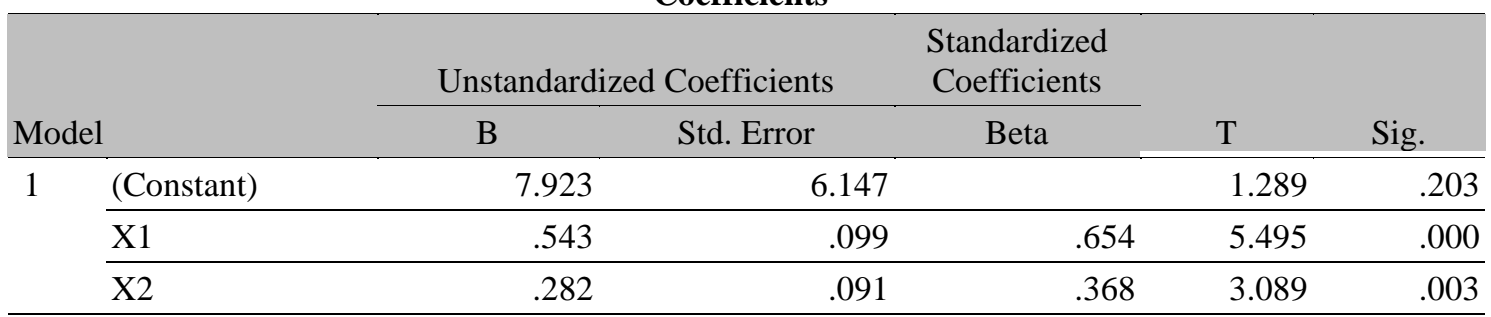

a. Dependent Variable: Y

Sumber : Data Primer diolah dengan SPSS berikut :

Dari hasil output di atas dapat diinterpretasikan masing-masing pengaruh antar variabel sebagai

Variabel kompensasi (X1) mempunyai nilai t-hitung 5,495 yang lebih besar dari nilait-tabel dengan tingkat signifikansi sebesar 0.000 dan $\alpha$ (alpha) yang digunakan sebesar $0.05(0.000<0.05)$ artinya hipoteesis $\mathrm{H} 1$ diterima dan $\mathrm{H} 0$ ditolak. Hal ini membuktikan bahwa secara parsial variabel kompensasi (X1) berpengaruh positif dan signifikan terhadap variabel semangat kerja pegawai (Y). Temuan ini memberikan implikasi bahwa proses pemberian kompensasi dapat meningkatkan semangat kerja pegawai. Hasil penelitian diperkuat dengan hasil penelitian Danti (2014) menunjukkan bahwa kompensasi langsung dan tidak langsung berpengaruh terhadap semangat kerja pegawai.

Variabel Komunikasi (X2) mempunyai nilai t-hitung sebesar 3,089 dengan tingkat signifikansi sebesar 0.003 dan $\alpha$ (alpha) yang digunakan sebesar 0.05 maka sig $\mathrm{t}<\operatorname{sig} \alpha(0.003<0.05)$ sehingga $\mathrm{H} 2$ 
diterima dan $\mathrm{H} 0$ ditolak. Hal ini membuktikan bahwa secara parsial variabel komunikasi (X2) berpengaruh signifikan terhadap semangat kerja pegawai (Y)

\section{Uji-F (Pengujian Secara Simultan)}

Uji statistik F menunjukkan apakah semua variabel bebas mempunyai pengaruh secara simultan terhadap variabel terikat. Hasil uji-F simultan adalah sebagai berikut :

Tabel 9. Hasil Uji Hipotesis Simultan (Uji F)

\begin{tabular}{|c|c|c|c|c|c|c|}
\hline \multicolumn{7}{|c|}{ ANOVA $^{b}$} \\
\hline & & Sum of Squares & Df & Mean Square & $\mathrm{F}$ & Sig. \\
\hline \multirow[t]{3}{*}{1} & Regression & 326.975 & 2 & 163.487 & 15.770 & $.000^{\mathrm{a}}$ \\
\hline & Residual & 518.346 & 50 & 10.367 & & \\
\hline & Total & 845.321 & 52 & & & \\
\hline
\end{tabular}

a. Predictors: (Constant), X2, X1

b. Dependent Variable: Y

Sumber : Data Primer, diolah 2021

Berdasarkan tabej 9 di atas menunjukkan bahwa nilai F-hitung adalah sebesar 15,770 dengan nilai signifikansi (Sig) hasil penelitian sebesar 0.000 sedangkan $\alpha$ (alpha) yang digunakan dalam penelitian ini sebesar 0.05 sehingga signifikansi (Sig) $0.000<0.05$ yang berarti bahwa hipotesis $\mathrm{H} 3$ diterima dan H0 ditolak. Hal ini dapat disimpulkan bahwa secara simultan (bersama-sama) variabel kompensasi dan Komunikasi berpengaruh positif dan signifikan terhadap semangat kerja pegawai Dinas Tenaga Kerja dan Transmigrasi (Disnakertrans) Kabupaten Bima.

Hasil penelitian ini memperkuat penelitian dari Ni Luh Sri Widani (2018) bahwa kompensasi dan komunikasi berpengaruh signifikan secara simultan terhadap semangat kerja karyawan Hotel Puri Dajuma Resort. Hal ini berarti kompensasi dan komunikasi secara bersama- sama mempengaruhi semangat kerja karyawan Hotel Puri Dajuma Resort.

\section{Pembahasan}

\section{Pengaruh Kompensasi Terhadap Semangat Kerja}

Berdasarkan hasil olah data diketahui bahwa variabel Kompensasi mempunyai nilai t-hitung sebesar 5,495, signifikansi sebesar 0,000 <0,05 dan koefisien beta standar sebesar 0,543. Makna dari hasil tersebut bahwa kompensasi berpengaruh positif dan signifikan terhadap semangat kerja pegawai. Oleh karena itu dapat disimpulkan bahwa hipotesis H1 yaitu kompensasi berpengaruh positif dan signifikan terhadap semangat kerja pegawai Dinas Tenaga Kerja dan Transmigrasi (Disnakertrans) Kabupaten Bima dapat dibuktikan atau diterima.

Kompensasi merujuk pada semua bentuk hasil keuangan dan tunjangan nyata yang diterima pegawai sebagai bagian dari hubungan kerja. Semangat kerja dapat dikatakan sebagai proses yang menjelaskan intensitas, arah dan ketekunan seseorang untuk mencapai tujuannya Tentunya dengan adanya hasil berupa keuangan maupun tunjangan yang diterima pegawai memberikan akibat pegawai lebih tekun dalam mencapai tujuannya sehingga dapat memberikan efek positif dalam bekerja. Semakin tinggi Kompensasi maka semakin tinggi pula semangat kerja. Demikian pula sebaliknya semakin rendah Kompensasi maka semakin rendah pula semangat kerja. Dengan demikian tentunya besarnya kompensasi mampu mempengaruhi perilaku pegawai yaitu meningkatkan semangat pegawai dalam bekerja dan meningkatkan kenyamanan pegawai selama bekerja sehingga pegawai memiliki komitmen yang tinggi, sehingga akan berefek pada kinerja yang dihasilkan.

Penelitian ini membuktikan bahwa kompensasi sangat penting dalam meningkatkan semangat kerja pegawai. Apabila pegawai dapat menunjukan prestasi kerja yang tinggi dan kemudian organisasi memberikan reward berupa kompensasi yang layak maka motivasi dan semangat pegawai akan semakin tinggi sehingga pegawai akan berusaha meningkatkan kinerjanya. Hal ini sejalan dengan pendapat Notoadmojo (2012), bahwa tujuan dari kompensasi yaitu untuk menghargai prestasi kerja, menjamin keadilan, mempertahankan pegawai, pengendalian biaya dan memenuhi peraturan-peraturan. Temuan ini memberikan implikasi bahwa proses pemberian kompensasi dapat meningkatkan semangat kerja pegawai. Hasil penelitian diperkuat dengan hasil penelitian Danti (2014) menunjukkan bahwa kompensasi langsung dan tidak langsung berpengaruh terhadap semangat kerja pegawai. 


\section{Pengaruh Komunikasi Terhadap Semangat Kerja}

Berdasarkan hasil olah data diketahui bahwa variabel komunikasi mempunyai nilai t-hitung sebesar 3,089, signifikansi sebesar 0,003 < 0,05 dan koefisien beta standar sebesar 0,282. Makna dari hasil tersebut adalah bahwa komunikasi berpengaruh positif dan signifikan terhadap semangat kerja pegawai. Oleh karena itu dapat disimpulkan bahwa hipotesis $\mathrm{H} 2$ yaitu komunikasi berpengaruh positif dan signifikan terhadap semangat kerja pegawai Dinas Tenaga Kerja dan Transmigrasi (Disnakertrans) Kabupaten Bima dapat dibuktikan atau diterima.

Dengan adanya komunikasi yang tepat dalam sebuah organisasi tentunya akan memberikan imbal balik antara pegawai dan organisasi sehingga semakin meningkatkan komitmen seorang pegawai dalam organisasi. Semakin baik komunikasi maka akan berdampak pada peningkatan semangat kerja pegawai. Demikian pula sebaliknya semakin buruk komunikasi antara atasan dengan pegawai maupun dengan sesama pegawai maka akan berdampak pada penurunan semangat kerja dan komitmen organisasional.

Berdasarkan hasil penelitian secara statistik menunjukkan bahwa komunikasi berpengaruh terhadap semangat kerja pegawai Dinas Tenaga Kerja dan Transmigrasi (Disnakertrans) Kabupaten Bima baik berupa komunikasi vertical yakni atasan dengan bawahan dan komunikasi horizontal yakni antara pegawai dengan pegawai di Dinas Tenaga Kerja dan Transmigrasi (Disnakertrans) Kabupaten Bima terjalin dengan baik. Informasi dari bawahan (pegawai) sampai kepada atasan (pimpinan) begitu sebaliknya pimpinan juga memberikan informasi dan perintah kepada pegawai sehingga dalam pekerjaan tidak terjadi miss communication.

Hasil penelitian inil membuktikan dan memperkuat hasil penelitian terdahulu yang dilakukan Rochim (2012) yang menunjukkan bahwa komunikasi berpengaruh signifikan terhadap semangat kerja, artinya bahwa semakin inten komunikasi antara pimpinan dan pegawai akan berpengaruh terhadap semangat kerja.

\section{Pengaruh Kompensasi dan Komunikasi Terhadap Semangat Kerja}

Berdasarkan hasil penelitian secara statstik menunjukkan bahwa terdapat pengaruh positif dan signifikan kompensasi dan komunikasi secara simultan (bersama-sama) terhadap semangat kerja pegawai. Hal ini dibuktikan dari hasil analisis F-hitung adalah sebesar 15,770 dengan nilai signifikansi (Sig) hasil penelitian sebesar 0.000 sedangkan $\alpha$ (alpha) yang digunakan dalam penelitian ini sebesar 0.05 sehingga signifikansi (Sig) $0.000<0.05$. Oleh karena itu dapat disimpulkan bahwa hipotesis $\mathrm{H} 3$ yaitu kompensasi dan komunikasi berpengaruh positif dan signifikan terhadap semangat kerja pegawai Dinas Tenaga Kerja dan Transmigrasi (Disnakertrans) Kabupaten Bima dapat dibuktikan atau diterima.

Dilihat dari kontibusi hubungan kedua variabel kompensasi dan komunikasi terhadap variabel semangat kerja sebesar 0.622 sehingga dapat dinyatakan terdapat hubungan yang positif antara variabel kompensasi dan komunikasi terhadap semangat kerja pegawai Dinas Tenaga Kerja dan Transmigrasi (Disnakertrans) Kabupaten Bima yang dikategorikan cukup kuat. Hal ini menunjukkan bahwa variabel kompensasi dan komunikasi memiliki pengaruh kuat dalam menumbuhkan semangat kerja. Semakin baik komunikasi yang terjalin dalam organisasi dan besarnya kompensasi akan meningkatkan semangat kerja pegawai. Hasil penelitian ini sejalan dengan pendapat Hasibuan (2013) bahwa semua pendapatan yang berbentuk uang, barang langsung atau tidak langsung yang diterima pegawai sebagai imbalan atas jasa dan penghargaan atas prestasi kerja yang diberikan kepada kantor.

\section{SIMPULAN}

\section{Kesimpulan}

1. Kompensasi berpengaruh positif dan signifikan terhadap semangat kerja pegawai pada Dinas Tenaga Kerja dan Transmigrasi (Disnakertrans) Kabupaten Bima. Hal ini bermakna bahwa semakin baik kompensasi yang diberikan pegawai berupa finansial maupun fasilitas serta bonus dan penghargaan, maka semangat kerja pegawai semakin meningkat.

2. Komunikasi berpengaruh positif dan signifikan terhadap semangat kerja pegawai pada Dinas Tenaga Kerja dan Transmigrasi (Disnakertrans) Kabupaten Bima. Hal ini berarti semakin baik komunikasi yang terjalin antara pegawai dengan atasan maupun pegawai dengan rekan sejawat akan meningkatkan semangat kerja, karena dengan komunikasi yang intens permasalahan dalam organisasi akan mudah terselesaikan

3. Kompensasi dan komunikasi secara bersama-sama berpengaruh positif dan signifikan terhadap semangat kerja pegawai pada Dinas Tenaga Kerja dan Transmigrasi (Disnakertrans) Kabupaten 
Bima. Hal ini berarti komunikasi yang terjalin dengan baik dan kompensasi yang sesuai diberikan Saran akan menjadikan semangat kerja pegawai meningkat.

1. Kompensasi yang tinggi pada pegawai berimplikasi bahwa pada instansi akan memperoleh keuntungan dan manfaat maksimal dari pegawai karena besarnya kompensasi sangat ditentukan oleh tinggi/rendahnya produktivitas kerja pegawai. Banyaknya pegawai yang berprestasi tinggi akan mengurangi pengeluaran biaya untuk kerja yang tidak perlu yang diakibatkan oleh kurang efisien dan efektifitasnya kerja. Serta memberikan pujian atau penghargaan pegawai ketika meyelesaikan tugas dengan baik.

2. Pegawai hendaknya meningkatkan semangat kerja dengan mejalankan disiplin waktu yang ada pada Dinas Tenaga Kerja dan Transmigrasi (Disnakertrans) Kabupaten Bima. Hal ini dapat dlihat dari masih banyaknya pegawai yang masuk kantor tidak tepat waktu sesuai dengan aturan

3. Perlu membina hubungan dan komunikasi yang baik antara atasan dan pegawai serta sesama rekan kerja. Hal ini diperlukan agar kinerja pegawai Dinas Tenaga Kerja dan Transmigrasi (Disnakertrans) Kabupaten Bima dapat meningkat

4. Bagi peneliti selanjutnya, penelitian ini diharapkan dapat digunakan untuk memperkaya pengetahuan dan melengkapi literatur mengenai peran komunikasi dan kompensasi dengan mempertimbangkan aspek lainnya yang mempengaruhi semangat kerja pegawai.

\section{DAFTAR PUSTAKA}

Alex S. Nitisemito. 2013, Manajemen Personalia, Edisi Ketiga, Cetakan Kesembilan, Jakarta. Ghalia Indonesia.

Bangun, Wilson. 2012. Manajemen Sumber Daya Manusia. Erlangga. Jakarta.

Danti, Fajarini P, Moh.Soe'oed Hakam,Moch.Djudi Mukzam .2014. Pengaruh Kompensasi Terhadap Semangat Kerja Pegawai (Studi pada Pegawai CV.Sejahtera, Pakisaji, Malang).Jurnal Administrasi Bisnis (JAB) Vol.9 No.2.

Donni Junni Priansa 2014, Perencanaan \& Pengembangan SDM, Penerbit Bandung: Alfabeta

Dwi Agung Nugroho Arianto. 2015. Pengaruh Komunikasi Organisasi Dan Kompensasi Terhadap Semangat Kerja Pegawai. Jurnal Economia, Volume 11, Nomor 2,

Effendy, 2013. Kepemimpinan dan Komunikasi, Bandung. Mandar Maju.

Ghozali, Imam. 2016. Aplikasi Analisis Multivariete Dengan Program IBM SPSS 23 (Edisi 8). Cetakan ke VIII. Semarang : Badan Penerbit Universitas Diponegoro

Hasibuan, Malayu SP. 2014. Manajemen Sumber Daya Manusia, Cetakan keempat belas, Jakarta ,Penerbit : Bumi Aksara.

Hutapea, Parulian dan Nurianna Thoha, 2008, Kompetensi Plus : Teori, Desain, Kasus dan Penerapan untuk HR dan Organisasi yang Dinamis, Jakarta. Penerbit : Gramedia Pustaka Utama

Mangkunegara, Anwar Prabu. 2015. Sumber Daya Manusia Perusahaan. Bandung: Remaja Rosdakarya

Moekijat. 2012 Kamus Manajemen. Bandung: Penerbit CV. Mandar Maju

Ni Luh Sri Widani, 2018. Pengaruh Kompensasi Dan Komunikasi Terhadap Semangat Kerja Pegawai Pada Hotel Puri Dajuma Resort. Jurnal Pendidikan Ekonomi Undiksha. Vol. 10 No.1

Nurjanah Lateng Bustami, 2013. Pengaruh Kompensasi Terhadap Semangat Kerja Pegawai Tetap Pada PT. Perkebunan Nusantara XIV(Persero) Pola Kerja Sama Luwu. Jurnal Equilibrium. Vol.3 No. 2

Rochim, Nur. 2012 Analisis Pengaruh Komunikasi, Kepemimpinan dan Lingkungan Kerja terhadap Semangat Kerja Guru dan Karyawan. Jurnal Dinamika Manajemen, Vol. 1 (2), 103-113

Sekaran, U. dan Bougie, R. 2013. Research Methods for Business: A Skill-Building Approach. Sixth Edition. New York: Wiley

Simamora, Henry. 2014 Manajemen Sumber Daya Manusia. Edisi Ke-3. Yogyakarta: STIE YKPN Silalahi, Ulber, 2012, Metode Penelitian Sosial, Bandung. Refika Aditama. 
Sugiyono. 2017. Metode Penelitian Kualitatif: Untuk Penelitian yang Bersifat: Eksploratif, Enterpretif, Interaktif, dan Konstruktif. Bandung: Alfabeta

Sri Widodo Soedarso. 2015. Manajemen Sumberdaya Manusia : Teori, Prencanaan Strategi, Isu-Isu Utama Dan Globalisasi. Bandung : Manggu Media

Tohardi, Ahmad, 2012. Pemahaman Praktis Manajemen Sumber Daya Manusia. Bandung : Mandar Maju

Veithzal, Rivai, Ella Jauvani Sagala. 2011 Manajemen Sumber Daya Manusia Untuk Perusahaan Dari Teori Ke Praktek. PT Raja Grafindo Persada, Jakarta.

Winardi, 2011. Motivasi dan Pemotivasian dalam Manajemen, Rajawali, Jakarta 